\title{
Physicochemical, texture properties, and microstructure of yogurt using polymerized whey protein directly prepared from cheese whey as a thickening agent
}

\author{
Tianqi Fang ${ }^{1}$ and Mingruo Guo ${ }^{2,3 *}$ \\ ${ }^{1}$ Department of Food Science, College of Food Science and Engineering, Jilin University, Changchun, 130062, China \\ 2 Department of Nutrition and Food Sciences, College of Agriculture and Life Sciences, University of Vermont, Burlington 05405 \\ ${ }^{3}$ Department of Food Science, Northeast Agriculture University, Harbin, 150030, China
}

\section{ABSTRACT}

The aim of this study was to investigate suitability of polymerized whey protein prepared directly from cheese whey on the physicochemical, texture properties, and microstructure of the yogurt. The results indicated that addition of polymerized whey protein obtained by heating the liquid whey protein concentrate at $75^{\circ} \mathrm{C}$ for 10 min had no significant differences in $\mathrm{pH}$, titratable acidity, total solids, protein content, viscosity, texture, and syneresis between the yogurt with polymerized liquid whey protein (YWPS) and the yogurt with polymerized whey protein concentrate. However, the YWPS had significant differences in viscosity, texture, and syneresis compared with the control yogurt. Scanning electron micrographs of YWPS displayed a compact and homogeneous protein network for polymerized whey protein solution (PWPS) samples. The 4 yogurt samples were evaluated by the quantitative descriptive analysis method, and 14 sensory attributes were analyzed by principal component analysis. All 3 principal components had significant effects on the sensory profiles, accounting for $52.3,24.32$, and $10.8 \%$ of the variability in the results, respectively. Polymerized whey protein prepared directly from cheese whey may be a good protein base as a thickening agent for yogurt making.

Key words: cheese whey, polymerized whey protein, thickening agent

\section{INTRODUCTION}

Cheese whey is a byproduct of cheese-making (Castro et al., 2009). Biochemical and chemical oxygen demand

Received December 20, 2018.

Accepted April 27, 2019.

*Corresponding author: mguo@uvm.edu of whey can cause environmental pollution (Yadav et al., 2015; Remón et al., 2016). Whey proteins, once thought to be the waste product of cheese making, have received a lot of attention from researchers not only because of their availability but also because they have certain desirable functional properties and high nutritional value and is often used to fortify protein in dairy products (Mulvihill and Ennis, 2003). The functional properties of whey protein can be improved by formation of polymerized whey protein (PWP), including emulsifying properties, foaming capacity, and thermal properties (Schmitt et al., 2007; Nicolai et al., 2011). Therefore, formation of PWP provides new opportunities to expand whey protein applications. Heat treatment has been used to improve emulsification properties of whey proteins including whey protein concentrate (WPC) and whey protein isolate (WPI) in the food industry (Mensi et al., 2013). In addition, the heat-induced aggregation of whey proteins may improve turbidity, viscosity, surface hydrophobicity, and gelation of whey proteins to achieve the desired structure and sensory properties of certain foods (Ren et al., 2017). It has been reported that PWP improved the body texture and enhanced the water-holding capacity of fermented dairy foods ( $\mathrm{Li}$ and Guo, 2006).

Yogurt is one of the most consumed dairy products in the world (Cardines et al., 2018). Besides its nutritional value, the viscosity and rate of syneresis of yogurt are important indexes of sensory qualities and stability of yogurt products (Domagała et al., 2013). The most common means to improve the texture of yogurt is to increase the TS content of milk, which can be achieved by adding milk protein and solids (Zhang et al., 2015). Addition of PWP in yogurt making could improve the viscosity and syneresis of goat milk yogurt ( $\mathrm{Li}$ and Guo, 2006). Native whey proteins are not commonly used as an ideal thickening agent because their solutions have lower viscosity because of the compact approximate globular structures and low molecular weight (Fitzsimons et al., 2008). However, heating can be used to 
prepare soluble whey protein aggregates that enable whey protein to form high molecular weight complexes and thus increase the viscosity under certain conditions (Vardhanabhuti and Foegeding, 1999; Vardhanabhuti et al., 2001). Henriques et al. (2013) made it possible to incorporate liquid whey protein concentrates in set yogurt production, which was produced from cheese whey without expensive processing steps (e.g., evaporation and drying) for small- and medium-scale dairy plants. Therefore, we hypothesized that polymerized liquid whey protein concentrate prepared directly from Cheddar cheese whey may be a more effective thickening agent for full-fat yogurt production. By using this method, we may obtain an alternative way to prepare PWP through thermal aggregation of conventional dry products, such as WPC or WPI, in manufacturing fermented dairy products.

\section{MATERIALS AND METHODS}

\section{Materials}

High-temperature-sterilized cow milk ( $\geq 8.2 \%$ wt/ vol nonfat solids, $5 \% \mathrm{wt} / \mathrm{vol}$ protein, and $6 \% \mathrm{wt} / \mathrm{vol}$ fat) was purchased from a local supermarket (Huishan Dairy Industry Co., Ltd., Changchun, China). Freeze-dried starter cultures containing Streptococcus thermophilus and Streptococcus bifidobacterium (ABY3 , thermophilic yogurt culture) was purchased from Chr. Hansen (Horsholm, Denmark). Whey protein concentrate (WPC80) was provided by Hilmar (Hilmar, CA). Liquid whey was collected from Cheddar cheese production. All other reagents were purchased from Beijing Chemical Works (Beijing, China).

\section{Preparation of Liquid Whey Protein Concentrate Solution}

The fresh whey from Cheddar cheese manufacture was pasteurized $\left(60^{\circ} \mathrm{C}\right.$ for $\left.30 \mathrm{~min}\right)$ and prefiltered using screen mesh. The treated whey was subjected to microfiltration $(0.1 \mu \mathrm{m})$. The microfiltered whey was ultrafiltered using a $10 \mathrm{kDa}$ cut-off membrane to 25fold. The UF-treated whey was electrodialyzed to remove $90 \%$ of salt, and the final protein content of the liquid whey protein concentrate solution (WPS) was $8.0 \%$ (wt/vol).

\section{Preparation of PWP}

The liquid whey protein solutions were adjusted to $\mathrm{pH}(7.0,8.0$, or 9.0$)$ using $\mathrm{NaOH}(2 M)$. The solutions were subjected to different treatment protocol, heated at different temperatures $\left(70,75,80,85\right.$, or $\left.90^{\circ} \mathrm{C}\right)$ for 20 min at $\mathrm{pH} 7.0$, heated at $75^{\circ} \mathrm{C}$ for different times $(10,20,30,40,50$, or $60 \mathrm{~min})$ at $\mathrm{pH} 7.0$, and heated at $75^{\circ} \mathrm{C}$ for $20 \mathrm{~min}$ at different $\mathrm{pH}$ values $(7.0,8.0$, and 9.0). The obtained PWP solutions were kept at room temperature $\left(25 \pm 1^{\circ} \mathrm{C}\right)$ until further analysis. In this study, PWP (heated at $75^{\circ} \mathrm{C}$ for $20 \mathrm{~min}$ at neutral $\mathrm{pH}$ ) was selected for yogurt making obtain a higher viscosity of yogurt based on preliminary experiment. The WPC powder $(10 \mathrm{~g})$ was suspended in $100 \mathrm{~mL}$ of Milli-Q water (Millipore Corp., Milford, MA) and kept at $4^{\circ} \mathrm{C}$ overnight. The WPC solution was adjusted to $\mathrm{pH} 8.0$ using $\mathrm{NaOH}(2 M)$. The solution was heated at $85^{\circ} \mathrm{C}$ for $30 \mathrm{~min}$ as previously described (Shen et al., 2016).

\section{Preparation of Yogurt Samples}

Three batches of yogurt were produced with whole milk. Four different yogurt formulations were prepared: (1) conventional yogurt with no addition as a control, with (2) addition of polymerized whey protein solution (PWPS, directly prepared from cheese whey, 2\%, vol/ vol; YWPS), with (3) addition of WPS (liquid whey protein solution prepared from cheese whey, $2 \%$, vol/ vol; UNYWPS), and with (4) addition of polymerized whey protein prepared from commercial whey protein concentrate powder (PWPC, $2 \% \mathrm{vol} / \mathrm{vol}$; YWPC).

The whole milk were preheated $\left(60^{\circ} \mathrm{C}\right)$, mixed with sugars $(7 \%$, wt $/ \mathrm{vol})$, sterilized at $80^{\circ} \mathrm{C}$ for $20 \mathrm{~min}$, cooled to $42^{\circ} \mathrm{C}$, mixed with different whey protein solutions and yogurt starter (ABY-3), and fermented at 42 $\pm 1^{\circ} \mathrm{C}$ for $4 \mathrm{~h}$. The yogurts were then stored at $4^{\circ} \mathrm{C}$ for $18 \mathrm{~h}$ after cooling. The production process of yogurt samples is shown as Figure 1.

\section{Physicochemical Property Analysis}

The TS, total protein, fat, ash, and titratable acidity were determined according to AOAC International (2002). The $\mathrm{pH}$ values of samples were measured using a pH meter (PHS-3C, Jingke, Shanghai, China). The TS content was measured using an infrared dryer (Moisture Analyzer MA30, Sartorius, Göttingen, Germany). Protein content was measured by the Kjeldahl method and fat was measured by the Gerber method. Ash content was measured by dry-ashing using a muffle furnace (SX-2.5-12; Jingke). The content of carbohydrate was determined by the difference of the TS content minus other solid component contents as previously described (Guzmangonzalez et al., 2000; Smith et al., 2016). 


\section{Viscosity and Texture Profile Analysis}

After storage at $4^{\circ} \mathrm{C}$ for $18 \mathrm{~h}$, yogurt samples were equilibrated at room temperature for $2 \mathrm{~h}$. Viscosity was measured with a Brookfield viscometer (DV-III, Brookfield Engineering Labs Inc., Middleboro, MA) at $25^{\circ} \mathrm{C}$. Texture analysis was conducted on a texture analyzer (Brookfield Engineering Labs Inc.) at $25^{\circ} \mathrm{C}$. All measurements were performed using a fresh sample without breaking the original yogurt structure. A texture profile analysis model was run with a penetration distance of $30 \mathrm{~mm}$ using an acrylic cylindrical probe (diameter: $38.10 \mathrm{~mm}$; height: $20 \mathrm{~mm}$ ). The speed of the probe was
$1 \mathrm{~mm} / \mathrm{s}$ with a trigger of $4.5 \mathrm{~g}$. The hardness, adhesiveness, springiness, and cohesiveness of samples were all recorded.

\section{Syneresis Analysis}

The syneresis of the yogurt samples was measured gravimetrically according to Lucey et al. (1998) with some modifications. The samples of yogurt $(20 \mathrm{~g})$ were transferred into 50-mL centrifugal tubes. Then the samples were centrifuged (Avanti J-E, Beckman Coulter, Brea, CA) at $1,200 \times g$ for $20 \min \left(25^{\circ} \mathrm{C}\right)$, and the supernatants were removed and weighed. The syneresis

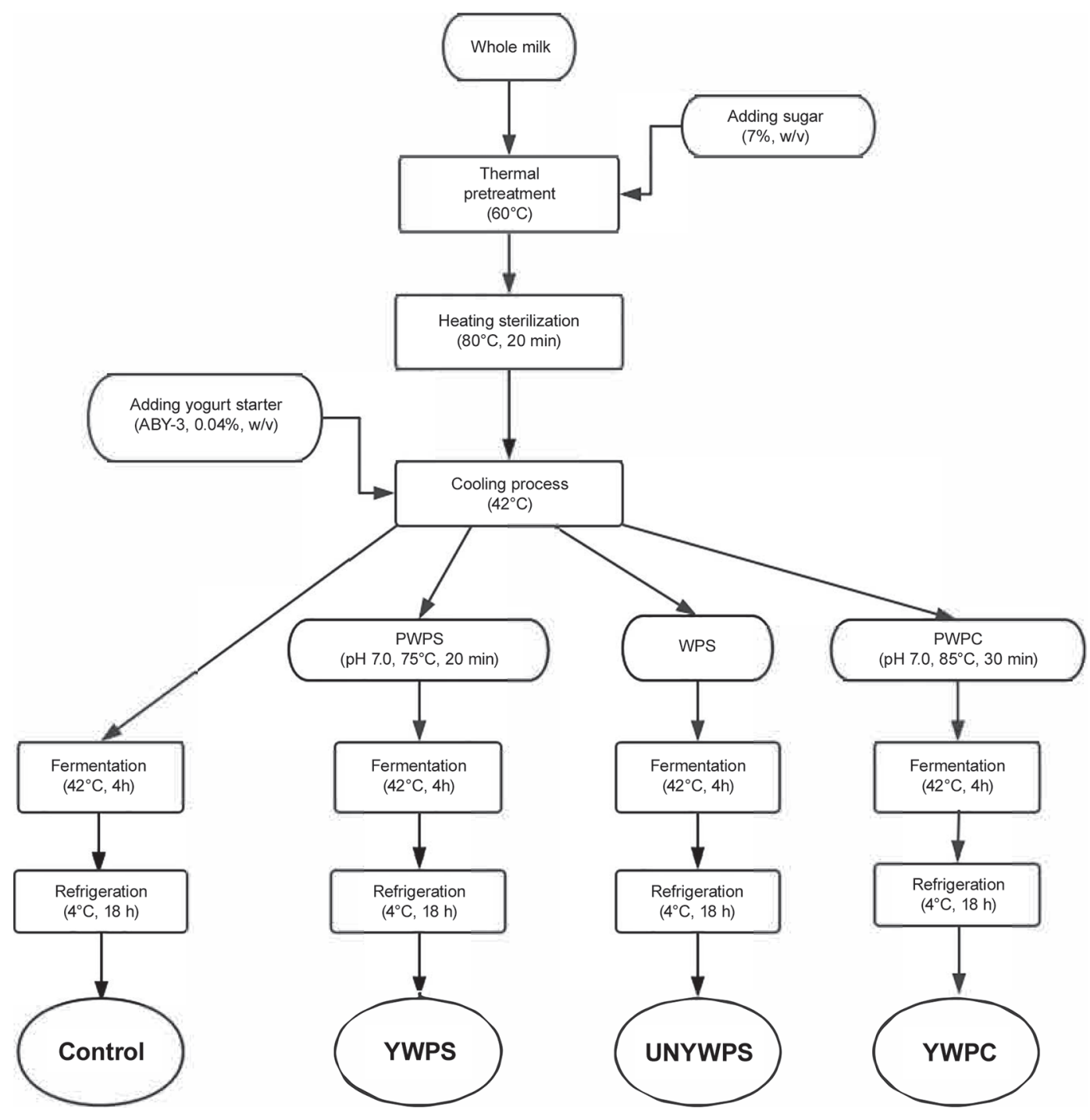

Figure 1. Schematic diagram of preparation process for different yogurt samples. Control = full-fat yogurt; YWPS = yogurt with addition of liquid polymerized whey protein (heated at $75^{\circ} \mathrm{C}$ for $20 \mathrm{~min}, \mathrm{pH} 7.0$ ); UNYWPS = yogurt with addition of unheated whey protein solids from cheese whey; YWPC = yogurt with heat-treated whey protein concentrate (heated at $80^{\circ} \mathrm{C}$ for $30 \mathrm{~min}, \mathrm{pH} 7.0$ ). PWPS $=$ polymerized whey protein solution; WPS = liquid whey protein solution; PWPC = polymerized whey protein prepared from commercial whey protein concentrate (WPC 80) The ABY-3 was purchased from Chr. Hansen (Horsholm, Denmark). 
Table 1. Definitions of the descriptors used in the sensory evaluation of the yogurt samples

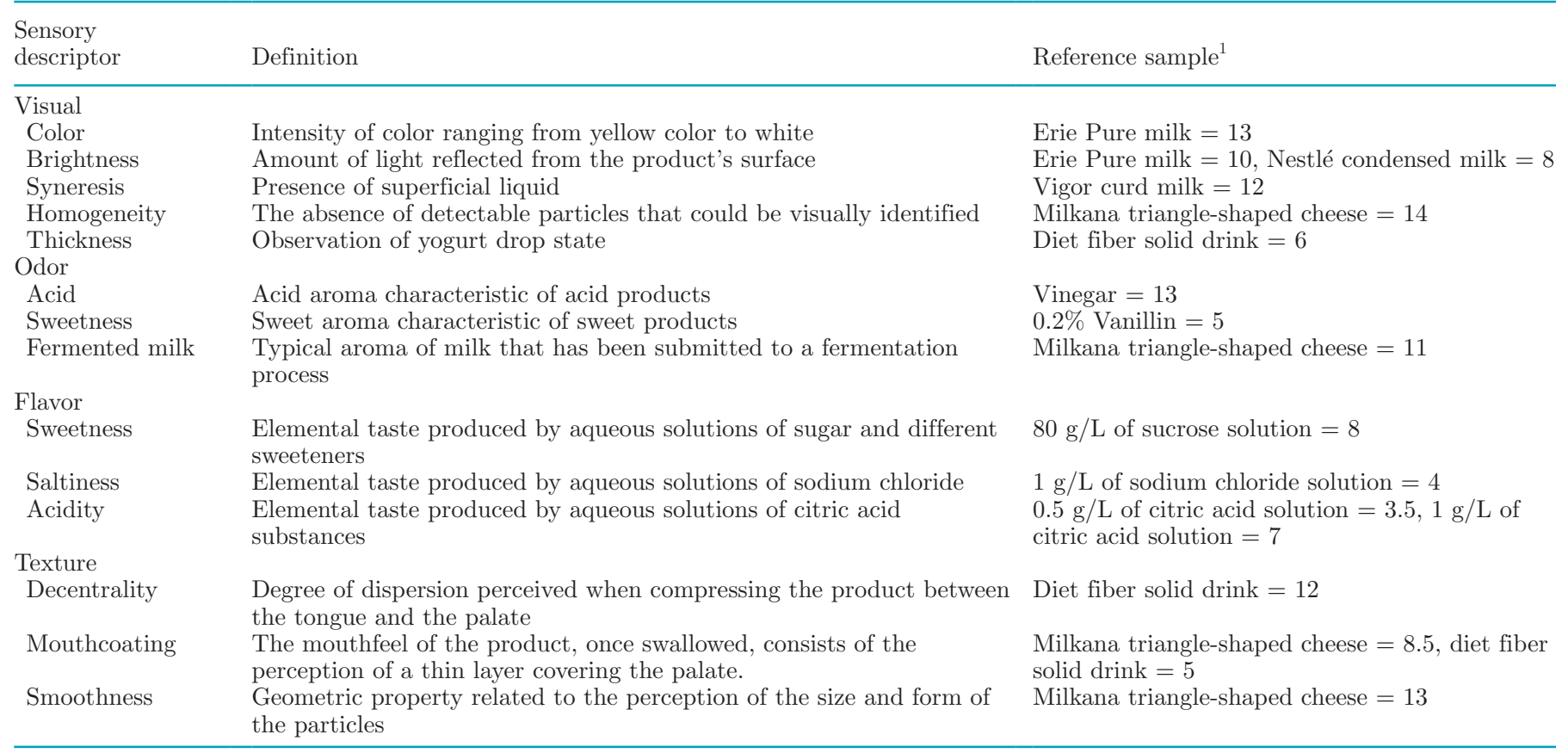

${ }^{1}$ Erie Pure milk (Erie, Mongolia Yili Industrial Group Co. Ltd., Inner Mongolia, China), containing 3.2\% protein, $3.8 \%$ fat, $5.0 \%$ carbohydrate, and higher than $8.5 \%$ of non-fat milk solids content, was purchased from local market. Nestlé condensed milk: Nestlé S.A., Vevey, Switzerland. Vigor curd milk: Dongguan Yiqun Food Co., Ltd., Dongguan, China. Milkana triangle-shaped processed cheese: BSI (Tianjin) Food Co., Ltd., Tianjin, China. Diet fiber solid drink: Jilin Senke Native Products Co., Ltd., Changchun, China.

was calculated as the percentage of the supernatant weight to yogurt weight.

\section{Microstructure Analysis}

Yogurt samples were examined by scanning electron microscopy according to the method previously described (Wang et al., 2017). Yogurt samples were fermented in the $2.5 \%$ agar cube $(1 \mathrm{~mm} \times 1 \mathrm{~mm} \times 1$ $\mathrm{mm}$ ) taken from below the surface and were fixed in the cube, incubated at $43^{\circ} \mathrm{C}$ for $4 \mathrm{~h}$, and then stored at $4^{\circ} \mathrm{C}$ overnight. The fixed samples were washed several times with $0.1 M$ phosphate buffer ( $\mathrm{pH} 7.2)$. The samples were then dehydrated using a series of increasing ethanol concentrations $(20,40,60,70$, and $90 \%)$ finishing with 3 changes of absolute alcohol. Dehydrated yogurt samples were freeze-dried using a freezer dryer (Alpha1-2, Christ Ltd., Vaihingen, Germany). Microstructure of yogurt samples were observed using scanning electron microscopy (JSM-6700F, Jeol Ltd., Tokyo, Japan).

\section{Sensory Evaluation}

Sensory evaluation was conducted by 12 panelists $(10$ female, 2 male), 20 to $30 \mathrm{yr}$ old, recruited from the Lab- oratory of Food Science Department, Jilin University (China). The sensory profile was established by using quantitative descriptive analysis (Gonzalez et al., 2011; Kaaki et al., 2012). All the panelists were selected after completing training according to ISO (1993) standards. The indicators of identity and quantity were evaluated using the reference properties as shown in Table 1. For all formulations, odor was the first property assessed and then the visual, flavor, and texture properties were evaluated. The intensity of the attributes was assessed using an evaluation sheet. Then $50 \mathrm{~mL}$ of the samples from the original containers were served at $4^{\circ} \mathrm{C}$ in random order under white light. The acceptability of the formulations were evaluated by 12 assessors of the products (Drake, 2007; Cruz et al., 2012) with a hedonic scale of 15 points $(15=$ very evident; $0=$ none $)$.

\section{Statistical Analysis}

All experiments were performed in triplicate. The results were expressed as mean \pm standard deviation. The data were analyzed by SPSS version 11.5 (SPSS Inc., Chicago, IL). The significance level was set at $P<$ 0.05 and $P<0.01$. All the figures were drawn by Origin 8.0 (OriginLab Corporation, Northampton, MA). 


\section{RESULTS AND DISCUSSION}

\section{Preliminary Results}

The effects of PWPS prepared through different treatment conditions $(\mathrm{pH}$, heating temperature, heating time) on the viscosity of yogurt samples (YWPS) are shown in Figure 2. The results showed that yogurt adding PWP prepared at different $\mathrm{pH}$, heating temperatures, and time had higher viscosity than that of yogurt without PWP. Heating the whey protein solution under controlled conditions to form a high molecular weight soluble whey protein aggregate results in an increase in viscosity (Vardhanabhuti and Foegeding, 1999). Figure 2A shows the yogurt samples contained PWP at different $\mathrm{pH}$ (7.0-9.0). No significant difference was observed in the viscosity of the yogurt sample with the addition of PWPS prepared between $\mathrm{pH} 7.0$ and $8.0(P>0.05)$. The viscosity of yogurt with the addition of PWPS prepared at $\mathrm{pH} 8.5$ and 9.0 was significantly higher than the control yogurt sample $(P$ $<0.01)$. The increasing in the viscosity of yogurt was due to the larger volume of casein micelles caused by the interaction between PWP and casein micelles (Dybowska, 2011). The viscosity tends to increases with the increase of heating temperature, which may be due to protein aggregation caused by protein unfolding, aggregation, or both (Dybowska, 2011). When the heating temperature reached $75^{\circ} \mathrm{C}$, the viscosity was at a peak of $3,683.33 \pm 86.23 \mathrm{mPas}$ and was significantly different from that of other samples $(P<0.05$; Figure $2 \mathrm{~B})$. Figure $2 \mathrm{C}$ shows that the relationship between heating time of PWP and viscosity of yogurts. No significant difference was observed in viscosity of yogurts added with PWP prepared by different heating time range from 20 to $60 \mathrm{~min}(P>0.05)$. However, the viscosity of yogurt with heating time as 10 min was significantly different from that of other yogurt samples $(P<0.05)$. Therefore, we selected $20 \mathrm{~min}$ as the optimal heating time. It has been reported that the viscosity of yogurt could be increased by the addition of PWP probably due to high level of cross-linking within the gel network during coagulation (Matumoto-Pintro et al., 2011).

\section{Physicochemical Properties}

The chemical composition of the experimental yogurt samples is shown in Table 2. The main reason for the decrease of $\mathrm{pH}$ during fermentation of yogurt was the lactic acid produced by Lactobacillus (Kailasapathy, 2006). The variation in $\mathrm{pH}$ and titratable acidity (TA) of yogurt samples may be due to the fact that the starter promotes hydrolysis of lactose in milk during fermentation (Wang et al., 2012). No significant difference was
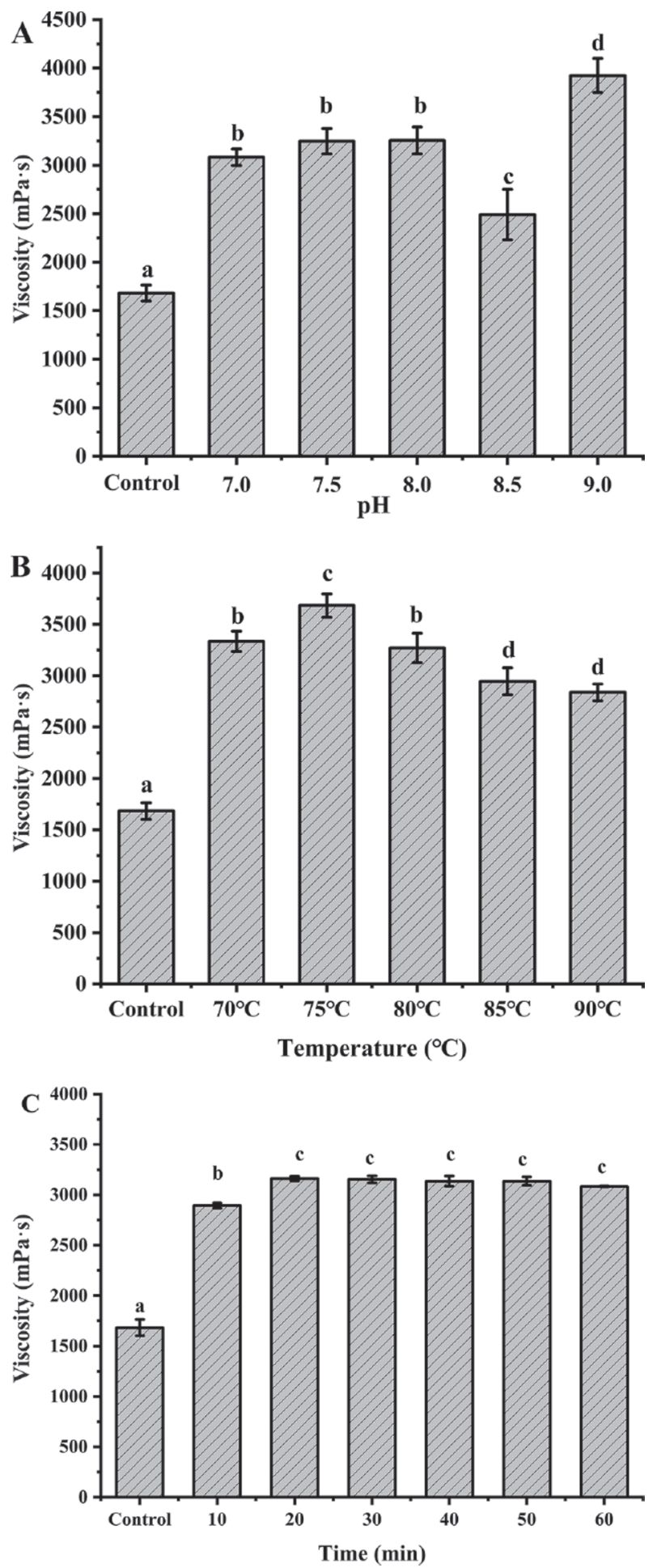

Figure 2. Effects of polymerized whey protein solution (PWPS) prepared through different treatment conditions ( $\mathrm{pH}$, heating temperature, and heating time) on the viscosity of yogurt samples. The PWPS were prepared at $75^{\circ} \mathrm{C}$ for 20 min at different $\mathrm{pH}$ values (A), at different temperatures for $20 \mathrm{~min}$ at $\mathrm{pH} 7.0$ (B), and at $75^{\circ} \mathrm{C}$ for different times at $\mathrm{pH} 7.0(\mathrm{C})$. Means in the graph indicated by different letters $(\mathrm{a}-\mathrm{d})$ are significantly different $(P<0.05)$ from other treatment conditions. Error bars represent the standard deviation (SD) of the mean of triplicate experiments. 
Table 2. Physicochemical properties of yogurt samples ${ }^{1}$

\begin{tabular}{|c|c|c|c|c|}
\hline Item & Control & YWPS & UNYWPS & YWPC \\
\hline $\mathrm{pH}$ & $4.27 \pm 0.02^{\mathrm{a}}$ & $4.45 \pm 0.03^{\mathrm{b}}$ & $4.32 \pm 0.01^{\mathrm{c}}$ & $4.47 \pm 0.03^{\mathrm{b}}$ \\
\hline Titratable acidity (\%) & $87.49 \pm 0.14^{\mathrm{a}}$ & $85.54 \pm 0.31^{\mathrm{b}}$ & $91.35 \pm 0.50^{\mathrm{c}}$ & $85.77 \pm 0.39^{\mathrm{b}}$ \\
\hline TS $(\%)$ & $11.88 \pm 0.07^{\mathrm{a}}$ & $12.62 \pm 0.34^{\mathrm{b}}$ & $12.23 \pm 0.10^{\mathrm{c}}$ & $12.50 \pm 0.37^{\mathrm{b}}$ \\
\hline Protein (\%) & $3.36 \pm 0.08^{\mathrm{a}}$ & $4.29 \pm 0.04^{\mathrm{b}}$ & $4.22 \pm 0.04^{\mathrm{bc}}$ & $4.32 \pm 0.03^{\mathrm{bd}}$ \\
\hline Fat $(\%)$ & $3.97 \pm 0.01^{\mathrm{a}}$ & $3.76 \pm 0.02^{\mathrm{b}}$ & $3.55 \pm 0.03^{\mathrm{c}}$ & $3.70 \pm 0.05^{\mathrm{b}}$ \\
\hline Lactose (\%) & $4.33 \pm 0.02$ & $4.38 \pm 0.11$ & $4.37 \pm 0.02$ & $4.29 \pm 0.01$ \\
\hline $\operatorname{Ash}(\%)$ & $0.67 \pm 0.02^{\mathrm{a}}$ & $0.73 \pm 0.01^{\mathrm{b}}$ & $0.75 \pm 0.01^{\mathrm{b}}$ & $0.76 \pm 0.01^{\mathrm{b}}$ \\
\hline
\end{tabular}

${ }^{\mathrm{a}-\mathrm{d}}$ Different lowercase letters within each row indicate a significant difference $(P<0.05)$ between yogurts.

${ }^{1}$ Values are means and SD of 2 replicates. Control $=$ full-fat yogurt; YWPS $=$ yogurt with liquid polymerized whey protein (heated at $75^{\circ} \mathrm{C}$ for $20 \mathrm{~min}, \mathrm{pH} 7.0$ ); UNYWPS = yogurt with unheated liquid whey protein; $\mathrm{YWPC}=$ yogurt with heat-treated whey protein concentrate (heated at $80^{\circ} \mathrm{C}$ for $30 \mathrm{~min}, \mathrm{pH} 7.0$ ).

observed in final $\mathrm{pH}$ value of YWPS and YWPC $(P$ $>0.05)$, which were higher $(P<0.05)$ than those of UNYWPS samples and control, indicative of a good yogurt (Bensmira and Jiang, 2012). The differences in TA were not significant between YWPS and YWPC $(P$ $>0.05)$, but the above 2 types of yogurt are lower than UNYWPS and control yogurt samples, and there was a significant difference between UNYWPS and control yogurt $(P<0.01)$. The TA values of yogurts may be associated with the nature of whey protein (heated or unheated), addition amounts, and $\mathrm{pH}$ values. The differences in TA were not significant between YWPS and YWPC $(P>0.05)$, but the above 2 types of yogurt are lower than UNYWPS and control yogurt samples, and a significant difference was observed between UNYWPS and control yogurt $(P<0.01)$. However, the TS content of the control sample was lower than that of the other 3 yogurt samples. The protein and fat contents in all variations ranged between 3.3 and $4.3 \mathrm{~g}$ per $100 \mathrm{~g}$, and 3.5 and $4.0 \mathrm{~g}$ per $100 \mathrm{~g}$, respectively. The ash content of
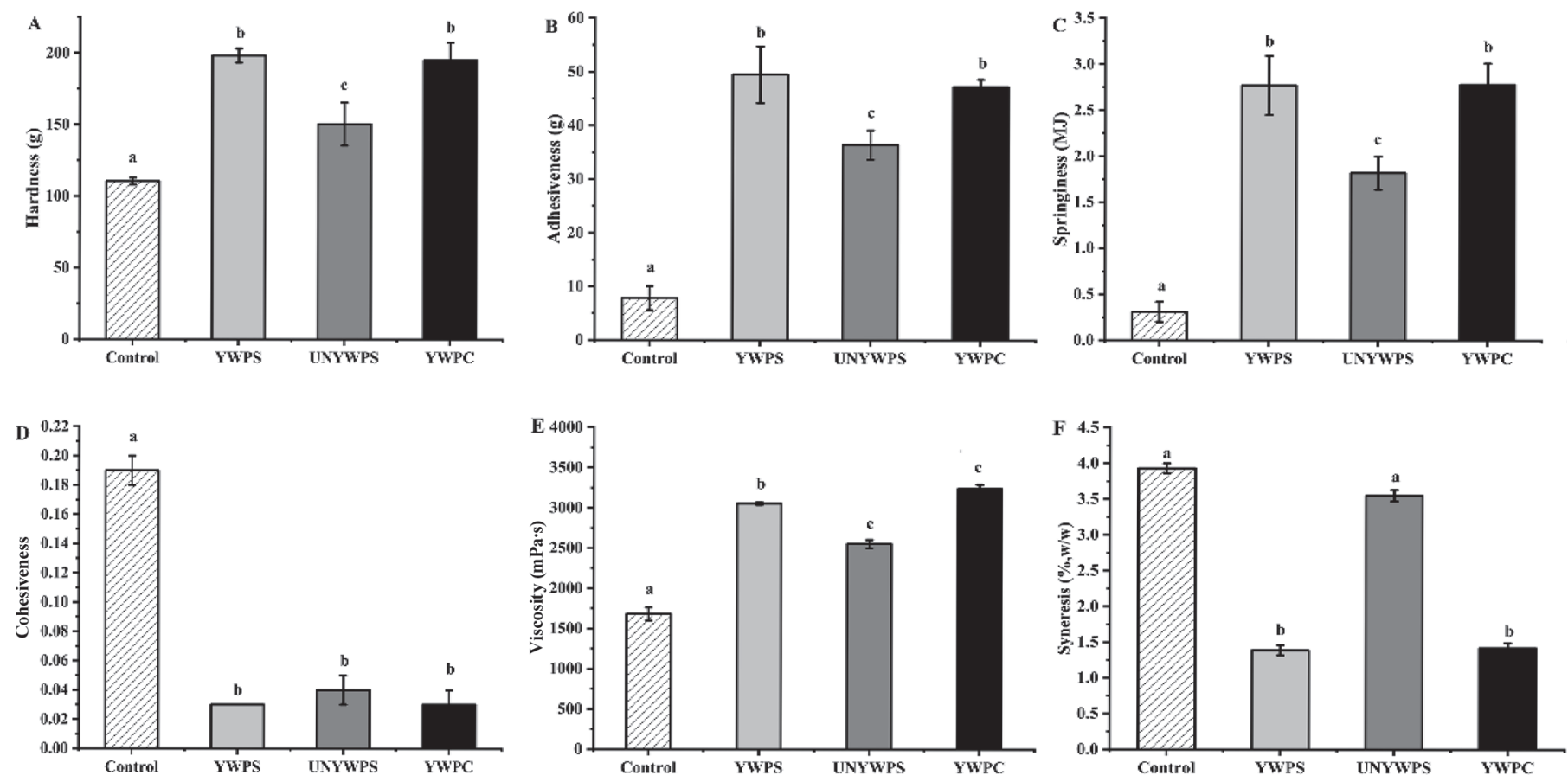

Figure 3. Comparison of yogurts prepared using different polymerized whey protein for hardness (A), adhesiveness (B), springiness (C), cohesiveness (D), viscosity (E), and syneresis $(\mathrm{F})$ of yogurt. Bars with different letters $(\mathrm{a}-\mathrm{c})$ are significantly different $(P<0.05)$. Control $=$ full-fat yogurt; YWPS = yogurt with addition of liquid polymerized whey protein (heated at $75^{\circ} \mathrm{C}$ for $20 \mathrm{~min}, \mathrm{pH} 7.0$ ); UNYWPS $=$ yogurt with unheated whey protein solids from cheese whey; YWPC $=$ yogurt with addition of heat-treated whey protein concentrate (heated at $80^{\circ} \mathrm{C}$ for $30 \mathrm{~min}, \mathrm{pH}$ 7.0). Means in the graph indicated by different letters $(\mathrm{a}-\mathrm{c})$ are significantly different $(P<0.05)$ from other treatment conditions. Error bars represent the standard deviation (SD) of the mean of triplicate experiments. 
yogurt contained different types of thickening agent in an amount significantly higher than the control yogurt sample $(P<0.05)$.

\section{Texture Profile and Viscosity}

Texture is one of the most essential indexes of yogurt quality (Sodini et al., 2004). The hardness, adhesiveness, springiness, cohesiveness, and viscosity of set yogurt are listed in Figure 3. Significant differences were observed in the textural properties of different yogurt samples $(P<0.05)$; YWPS, YWPC, and UNYWPS had thicker and tighter texture than the control yogurt. Incorporation of heat-treated WPS significantly $(P<0.05)$ increased the adhesiveness, hardness, and springiness, whereas addition of unheated WPS did not significantly affect the texture properties compared with the heat-treated WPC. Yogurt samples with the addition of PWP exhibited higher hardness (Figure 3A), adhesiveness (Figure 3B), and springiness values (Figure 3C) than control yogurt $(P<0.01)$. There was no significant difference in hardness, adhesiveness, and springiness values between YWPS and YWPC $(P>$
0.05). The YWPS had significant values in hardness, adhesiveness, and springiness values than UNYWPS $(P$ $<0.01)$. Yogurt samples with addition of PWP showed lower cohesiveness values than control yogurt $(P<$ 0.01; Figure 3D). However, the control yogurts showed higher values of cohesiveness than other samples and were shown to be significantly different from other yogurt samples $(P<0.01$; Figure 3$)$.

Compared with control, addition of whey proteins (WPS, PWPS, and PWPC) significantly increased the viscosity of the yogurt. The viscosity of YWPS was significantly higher than UNYWPS $(P<0.05)$. No significant difference was observed in viscosity between YWPS and YWPC $(P>0.05)$. The heat-treated WPS and WPC led to the formation of aggregated protein and influenced viscosity of yogurt, resulting in firmer structures. The viscosity of PWP was much higher than unheated whey protein solids, possibly due to the low molecular weight of native whey protein. The whey protein was heated to form a high molecular weight whey protein polymer similar to hydrocolloids and used as thickening agents in food products, similar to a previous study (Vardhanabhuti et al., 2001). The addition
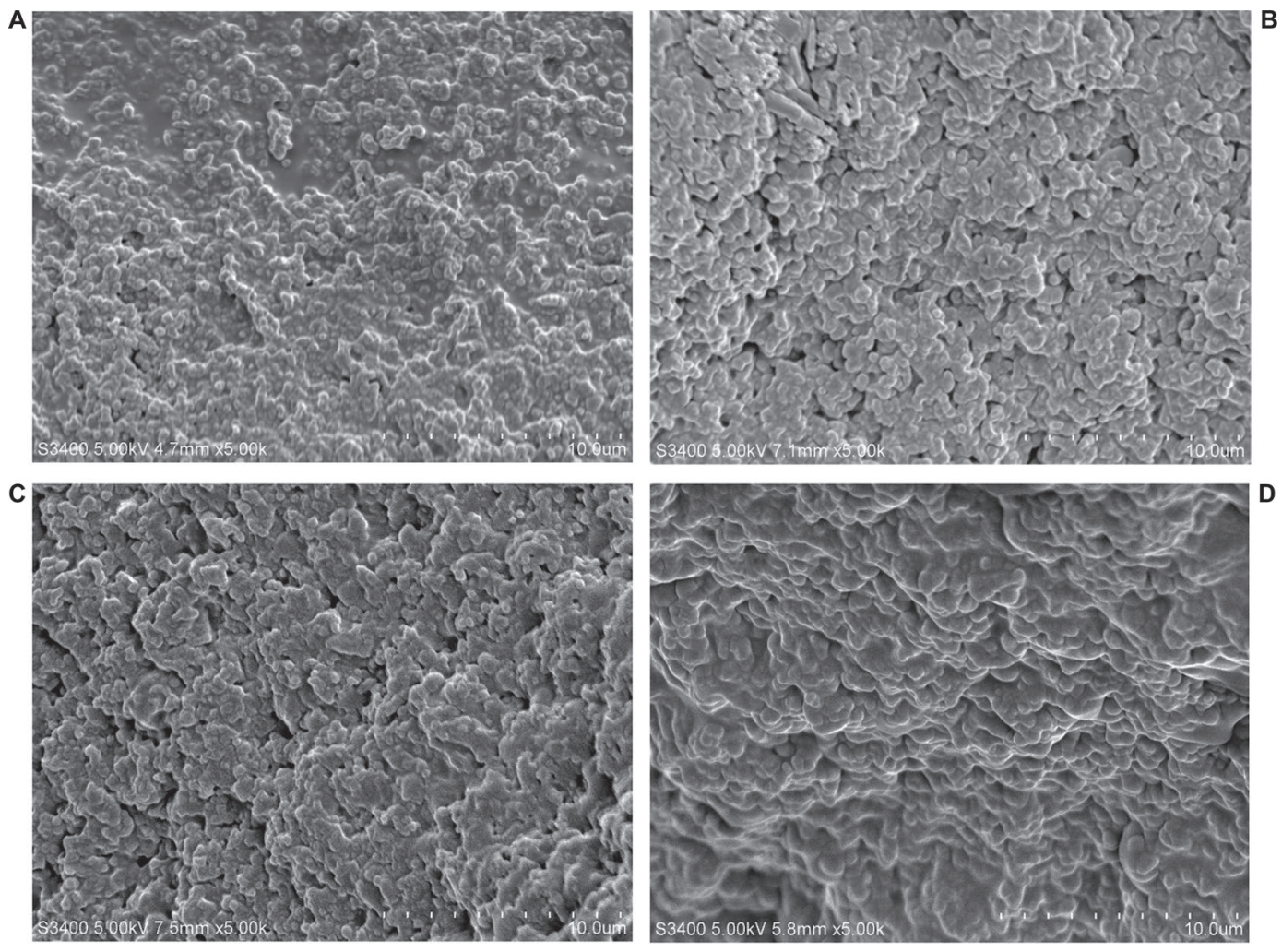

Figure 4. Scanning electron micrographs of 4 yogurt samples: (A) control = full-fat yogurt; (B) YWPS = yogurt with addition of liquid polymerized whey protein (heated at $75^{\circ} \mathrm{C}$ for $20 \mathrm{~min}, \mathrm{pH} 7.0$ ); (C) UNYWPS = yogurt with addition of unheated whey protein solids from cheese whey; and (D) YWPC = yogurt with addition of heat-treated whey protein concentrate (heated at $80^{\circ} \mathrm{C}$ for $30 \mathrm{~min}, \mathrm{pH} 7.0$ ). 
of PWP in yogurt making not only affects coagulation time but also the level of syneresis (Schorsch et al., 2001).

\section{Syneresis}

Syneresis is one of the important indexes to evaluate the quality of yogurt and is the major visible defect that occurs during yogurt storage (Ghorbanzade et al., 2017; Vianna et al., 2017). In Figure 3D, the results revealed that syneresis of the yogurt with heattreated WPS directly obtained by cheese whey yogurts (YWPS) was similar to that of YWPC $(P>0.05)$. However, the syneresis of the samples with PWP was lower than UNYWPC $(P<0.05)$, and there was significant difference with control yogurt $(P<0.01)$. The yogurt with unheated WPS had higher syneresis. This may be due to the protein-water interactions resulting in a weaker texture of yogurt with the addition of unheated WPS (Cheng et al., 2017). The control yogurt showed a higher value of syneresis than other samples $(P<0.01)$. Similar to Britten's (de Wit, 1989) theory, our results demonstrate that the addition of PWP to yogurt reduced syneresis of yogurt. However, Schorsch et al. (2001) showed that the gel formed by heat-treated whey protein and casein micelles was more likely to produce syneresis. The contradiction of the syneresis could be due to the different gel system, PWP manufacture conditions, and storage temperature. Because the whey protein gel has strong water-retaining capacity and PWP has the characteristics of an acidinduced cold gel, yogurt with added PWP can maintain the stability of the water phase in the yogurt network, thus reducing its susceptibility to syneresis ( $\mathrm{Li}$ and Guo, 2006). On the other hand, from the structure of the yogurt shown in the micrographs (Figure 4), PWP adsorption on the surface of the casein micelles forms casein/PWP complexes, making the protein networks

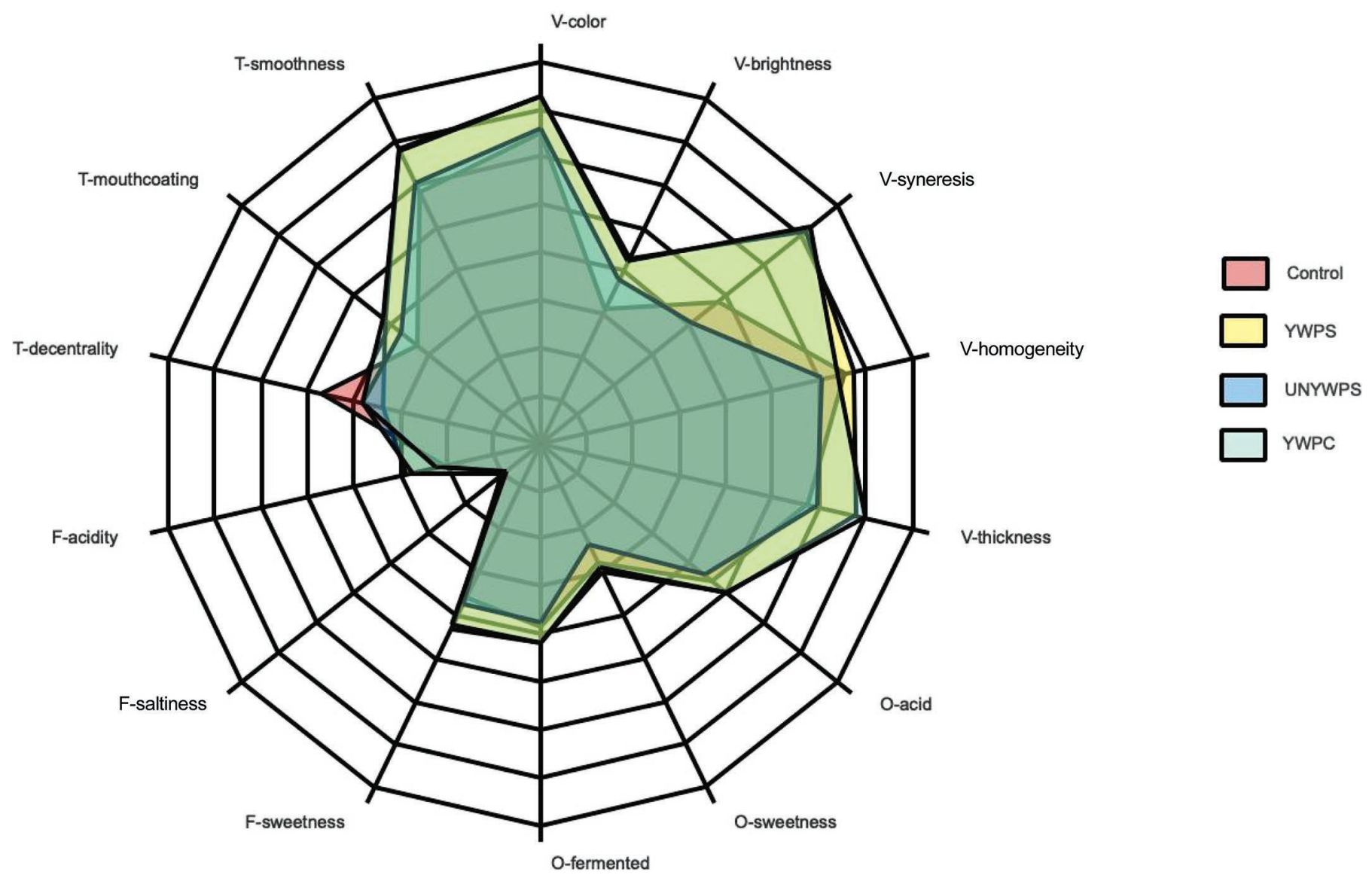

Figure 5. Sensory results from quantitative descriptive analysis from 4 yogurt samples: control = full-fat yogurt; YWPS $=$ yogurt prepared with polymerized whey protein solids (heated at $75^{\circ} \mathrm{C}$ for $20 \mathrm{~min}, \mathrm{pH} 7.0$ ) from cheese whey; UNYWPS $=$ yogurt with unheated whey protein solids from cheese whey; YWPC $=$ yogurt with heat-treated whey protein concentrate (heated at $80^{\circ} \mathrm{C}$ for $30 \mathrm{~min}, \mathrm{pH} 7.0$ ) of 14 major attributes. $\mathrm{T}=$ texture; $\mathrm{V}=$ visual $; \mathrm{O}=$ odor; $\mathrm{F}=$ flavor. 
of the yogurt more uniform, which may cause the synergistic effect network to weaken with the decrease of pore size (Farnsworth et al., 2006).

\section{Microstructure}

Scanning electron micrographs of yogurt samples are shown in Figure 4: control (A), YWPS (B), UNYWPS $(\mathrm{C})$, and YWPC (D). The scanning electron micrograph revealed that the distribution of casein micelles was relatively uniform and the size was relatively similar. In comparison with control yogurt (Figure 4A), yogurt samples with addition of whey proteins, such as YWPS (Figure 4B), UNYWPS (Figure 4C), and YWPC (Figure 4D), formed larger and denser protein clusters. A previous study found that addition of preheated whey proteins to casein micelles resulted in formation of bridges between the casein particles by binding with denatured whey protein to the surface of micelle during acidification (Schorsch et al., 2001). Scanning electron microscopy analysis of the microstructure of yogurt showed that the yogurt with denatured WPS formed a more comprehensive network structure that improved the water retention ability. Differences were observed in texture and microstructure of yogurt with different types of stabilizers, which may be due to the different stabilization mechanisms of different thickeners, thus

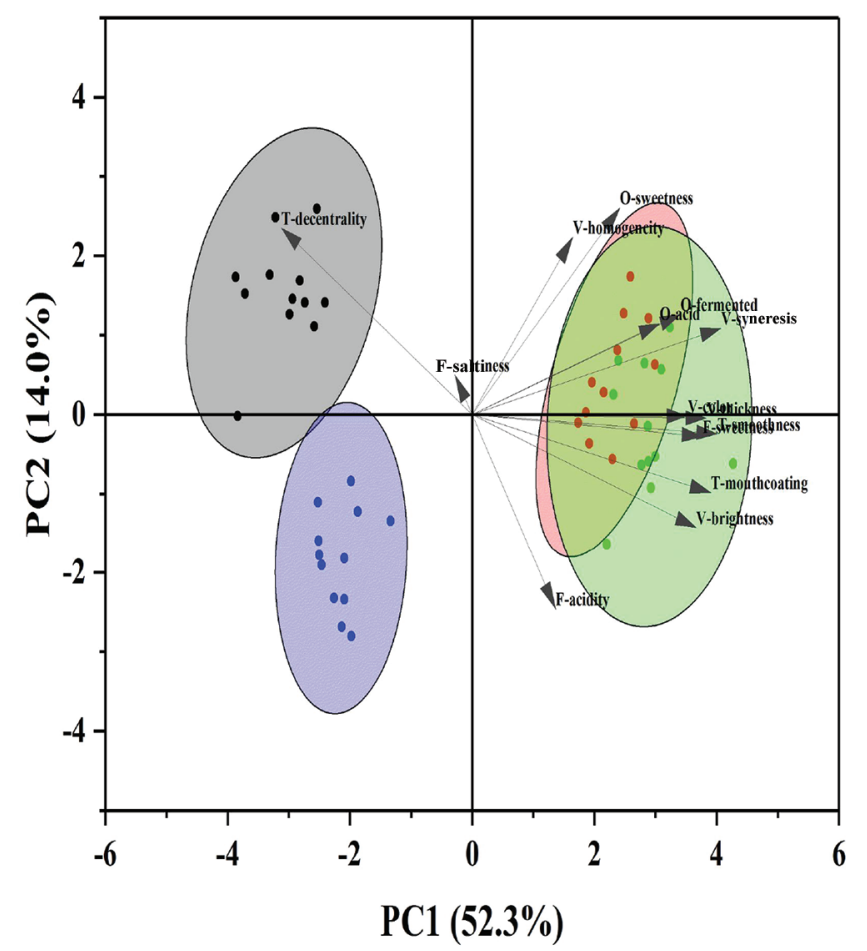

affecting the electrostatic interactions between protein molecules in the network. The direct interaction between casein micelle and denatured whey protein was observed from Figure 4, probably because the interaction between casein micelle and PWP mainly leads to the formation of casein-PWP complex through hydrophobic action. The combination of PWP and micelle surface helps to form a bridge between casein particles and form a network structure, which improves the consistency and increases the water retention of yogurt.

\section{Sensory Property}

A selected yogurt sample (YWPS) with added PWP was evaluated by sensory analysis in comparison to the control yogurt, UNYWPS, and YWPC. Each of the yogurt samples was tested for the 14 major sensory attributes (Table 1) and the sensory scores were presented in the spider diagram in Figure 5 (Nguyen et al., 2017). The intensity of each characteristic expressed by different yogurt samples in the same sensory properties was different. However, no significant difference $(P$ $>0.05)$ was observed between the YWPC and YWPS in sensory evaluation indexes. These 2 kinds of yogurt were compared with UNYWPS having differences $(P$ $<0.05)$ in various indicators and being significantly higher $(P<0.01)$ than the control sample in sensory

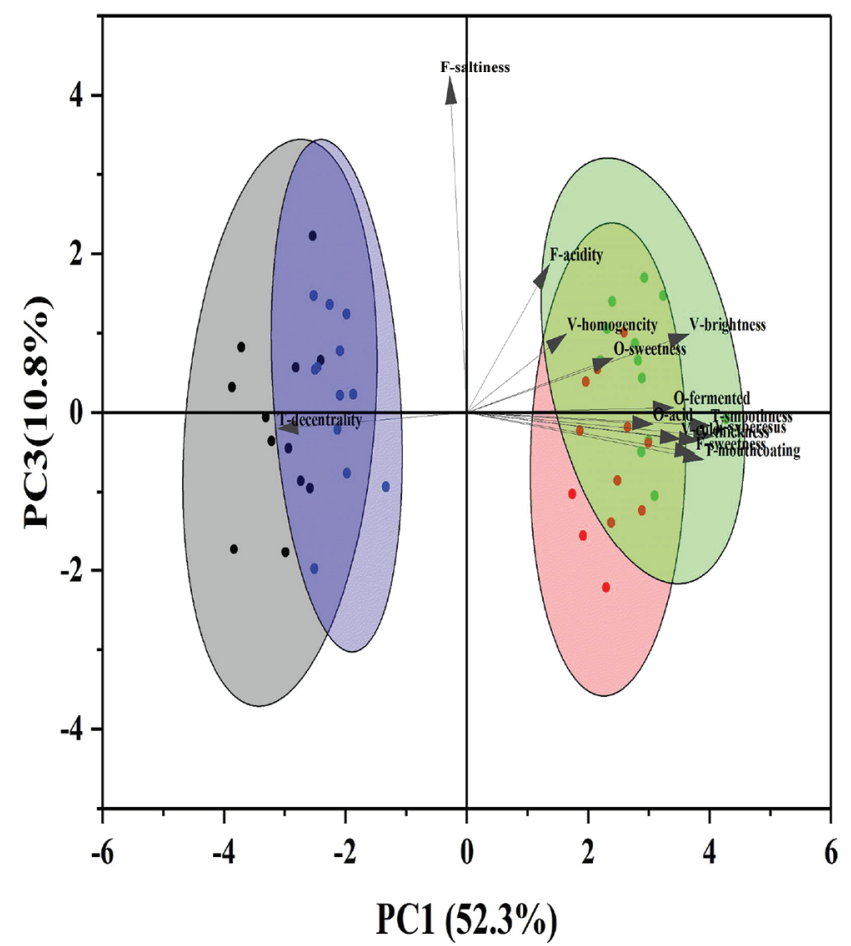

Figure 6. Principal component (PC) analysis biplots of the 4 yogurt samples including PC1 and PC3, and PC1 and PC2. Identification of samples is given in Table $1 . \mathrm{T}=$ texture; $\mathrm{V}=$ visual; $\mathrm{O}=$ odor; $\mathrm{F}=$ flavor. 
evaluation indexes except for texture (T)-dencentrality. This may be due to the higher viscosity and lower syneresis of the yogurt with added thickening agents (YWPC and YWPS), and sensory evaluation results have been consistent with the results shown in the Figure 3. Some studies have shown that the assessors after training were correlated positively with food preferences although sensory measurements are still subjective (Lopez-Enriquez et al., 2015; Tahsiri et al., 2017).

Principal component analysis was performed on sensory scores for 4 yogurt samples and the 14 attributes as shown in Table 1 . The principal component analysis biplot of the yogurt samples (Figure 6) illustrates specific differences among the products. The biplot explains $87.42 \%$ of the total variation as shown in Figure 6 . The first 2 principal components accounted for $52.3 \%$ of the variability in the results. The main loading factor included visual (V)-syneresis, V-thickness, flavor (F)sweetness, T-mouthcoating, and T-smoothness. The second principal components accounted for $24.32 \%$ of the variability in the results, which included T-decentrality, V-homogeneity, odor ( $\mathbf{O})$-sweetness, and F-acidity. The third factor on the y-axis explaining $10.8 \%$ is shown on the 3-dimensional diagram of Figure 6. There was similar distribution between the YWPC and YWPS in the positive part of the first dimension, and they were similar to each other in visual, odor, flavor, and texture aspects mentioned in Table 1, and the sensory characteristics such as T-mouthcoating, T-smoothness, and $\mathrm{V}$-syneresis were particularly obvious. Attribute vectors for T-decentrality, V-homogeneity, O-sweetness, and Facidity form the second principal dimension. In terms of T-decentrality, the 4 yogurt samples could be divided into 2 groups: lower decentrality (YWPC and YWPS) and higher decentrality (control and UNYWPS). The control yogurt sample was similar to UNYWPS in sensory index, but the 2 yogurt samples mentioned above were significantly different from YWPC and YWPS. It may be that the effect of viscosity of yogurt was related to adding a variety of polymeric whey proteins as the thickening agent, resulting in different decentrality of yogurt samples and affecting sensory evaluation of yogurt (Tahsiri et al., 2017).

\section{CONCLUSIONS}

Polymerized liquid whey protein concentrate prepared directly from Cheddar cheese whey can be used as a thickening agent for full-fat yogurt formulation. This procedure provides an alternative way to prepare PWP obtained through thermal aggregation of conventional dry products, such as WPC or WPI, in manufacturing these dairy products.

\section{ACKNOWLEDGMENTS}

The authors thank the Ministry of Science and Technology of China (project no. 2013BAD18B07) for financial support of this project.

\section{REFERENCES}

AOAC International. 2002. Association of Official Analytical Chemists: Official Methods of Analysis, Vol. II, 17th ed. AOAC Int., Gaithersburg, MD.

Bensmira, M., and B. Jiang. 2012. Rheological characteristics and nutritional aspects of novel peanut based kefir beverages and whole milk kefir. Int. Food Res. J. 58:96-109.

Cardines, P. H. F., A. T. A. Baptista, R. G. Gomes, R. Bergamasco, and A. M. S. Vieira. 2018. Moringa oleifera seed extracts as promising natural thickening agents for food industry: Study of the thickening action in yogurt production. LWT 97:39-44.

Castro, F. P. D., T. M. Cunha, P. J. Ogliari, R. F. Teófilo, M. M. C. Ferreira, and E. S. Prudêncio. 2009. Influence of different content of cheese whey and oligofructose on the properties of fermented lactic beverages: Study using response surface methodology. Lebensm. Wiss. Technol. 42:993-997.

Cheng, J., S. Xie, Y. Yin, X. Feng, S. Wang, M. Guo, and C. Ni. 2017. Physiochemical, texture properties, and the microstructure of set yogurt using whey protein-sodium tripolyphosphate aggregates as thickening agents. J. Sci. Food Agric. 97:2819-2825.

Cruz, A. G., W. F. Castro, J. A. F. Faria, P. C. B. Lollo, J. AmayaFarfán, M. Q. Freitas, D. Rodrigues, C. A. F. Oliveira, and H. T. Godoy. 2012. Probiotic yogurts manufactured with increased glucose oxidase levels: Postacidification, proteolytic patterns, survival of probiotic microorganisms, production of organic acid and aroma compounds. J. Dairy Sci. 95:2261-2269.

de Wit, J. N. 1989. Functional properties of whey proteins. Pages 285-321 in Developments in Dairy Chemistry, Volume 4: Functional Milk Proteins. P. F. Fox, ed. Applied Science Publishers, New York, NY.

Domagała, J., M. Wszołek, A. Y. Tamime, and B. Kupiec-Teahan. 2013. The effect of transglutaminase concentration on the texture, syneresis and microstructure of set-type goat's milk yoghurt during the storage period. Small Rumin. Res. 112:154-161.

Drake, M. A. 2007. Invited review: Sensory analysis of dairy foods. J. Dairy Sci. 90:4925-4937.

Dybowska, B. E. 2011. Whey protein-stabilized emulsion properties in relation to thermal modification of the continuous phase. J. Food Eng. 104:81-88.

Farnsworth, J. P., J. Li, G. M. Hendricks, and M. R. Guo. 2006. Effects of transglutaminase treatment on functional properties and probiotic culture survivability of goat milk yogurt. Small Rumin. Res. 65:113-121.

Fitzsimons, S. M., D. M. Mulvihill, and E. R. Morris. 2008. Segregative interactions between gelatin and polymerised whey protein. Food Hydrocoll. 22:485-491.

Ghorbanzade, T., S. M. Jafari, S. Akhavan, and R. Hadavi. 2017. Nano-encapsulation of fish oil in nano-liposomes and its application in fortification of yogurt. Food Chem. 216:146-152.

Gonzalez, N. J., K. Adhikari, and M. F. Sancho-Madriz. 2011. Sensory characteristics of peach-flavored yogurt drinks containing prebiotics and synbiotics. Lebensm. Wiss. Technol. 44:158-163.

Guzmangonzalez, M., F. Morais, and L. Amigo. 2000. Influence of skimmed milk concentrate replacement by dry dairy products in a low-fat set-type yoghurt model system. Use of caseinates, co-precipitate and blended dairy powders. J. Sci. Food Agric. 80:433-438.

Henriques, M. H. F., D. M. G. S. Gomes, C. J. D. Pereira, and M. H. M. Gil. 2013. Effects of liquid whey protein concentrate on functional and sensorial properties of set yogurts and fresh cheese. Food Bioprocess Technol. 6:952-963.

ISO. (International Organization for Standardization). 1993. ISO 85861: Sensory analysis - General guidance for the selection, training 
and monitoring of assessors-Part 1: Selected assessors. Accessed Jun. 19, 2019. https://www.iso.org/standard/15875.html.

Kaaki, D., B. O. Kebbe, N. E. Najm, and A. Olabi. 2012. Preference mapping of commercial Labneh (strained yogurt) products in the Lebanese market. J. Dairy Sci. 95:521-532.

Kailasapathy, K. 2006. Survival of free and encapsulated probiotic bacteria and their effect on the sensory properties of yoghurt. Lebensm. Wiss. Technol. 39:1221-1227.

Li, J. C., and M. Guo. 2006. Effects of polymerized whey proteins on consistency and water-holding properties of goat's milk yogurt. J. Food Sci. 71:C34-C38.

Lopez-Enriquez, R. L., V. M. Ocano-Higuera, W. Torres-Arreola, J. M. Ezquerra-Brauer, and E. Marquez-Rios. 2015. Chemical and functional characterization of sarcoplasmic proteins from giant squid (Dosidicus gigas) mantle. J. Chem. 2015:538721.

Lucey, J. A., M. Tamehana, H. Singh, and P. A. Munro. 1998. A comparison of the formation, rheological properties and microstructure of acid skim milk gels made with a bacterial culture or glucono- $\delta$ lactone. Food Res. Int. 31:147-155.

Matumoto-Pintro, P. T., L. Rabiey, G. Robitaille, and M. Britten. 2011. Use of modified whey protein in yoghurt formulations. Int. Dairy J. 21:21-26.

Mensi, A., Y. Choiset, T. Haertle, E. Reboul, P. Borel, C. Guyon, M. Lamballerie, and J. M. Chobert. 2013. Interlocking of $\beta$-carotene in beta-lactoglobulin aggregates produced under high pressure. Food Chem. 139:253-260.

Mulvihill, D. M. and M. P. Ennis. 2003. Functional milk proteins: Production and utilization. Pages 1175-1228 in Advanced Dairy Chemistry-1. P. F. Fox and P. L. H. McSweeney, ed. Springer, Boston, MA.

Nguyen, P. T. M., O. Kravchuk, B. Bhandari, and S. Prakash. 2017. Effect of different hydrocolloids on texture, rheology, tribology and sensory perception of texture and mouthfeel of low-fat pot-set yoghurt. Food Hydrocoll. 72:90-104.

Nicolai, T., M. Britten, and C. Schmitt. 2011. $\beta$-Lactoglobulin and WPI aggregates: Formation, structure and applications. Food Hydrocoll. 25:1945-1962.

Remón, J., L. García, and J. Arauzo. 2016. Cheese whey management by catalytic steam reforming and aqueous phase reforming. Fuel Process. Technol. 154:66-81.

Ren, F., D. Dong, B. Yu, Z. H. Hou, and B. Cui. 2017. Rheological, thermal properties and microstructure of heat-induced gel of whey protein-acetylated potato starch. Starke 69. https://doi.org/10 $.1002 /$ star.201600344.

Schmitt, C., C. Bovay, M. Rouvet, S. Shojaei-Rami, and E. Kolodziejczyk. 2007. Whey protein soluble aggregates from heating with $\mathrm{NaCl}$ : Physicochemical, interfacial, and foaming properties. Langmuir 23:4155-4166.
Schorsch, B. C., D. K. Wilkins, M. G. Jonest, and I. T. Norton. 2001 Gelation of casein-whey mixtures: Effects of heating whey proteins alone or in the presence of casein micelles. J. Dairy Res. $68: 471-481$.

Shen, X., T. Fang, F. Gao, and M. Guo. 2016. Effects of ultrasound treatment on physicochemical and emulsifying properties of whey proteins pre- and post-thermal aggregation. Food Hydrocolloids 63:668-676.

Smith, T. J., R. E. Campbell, and M. A. Drake. 2016. Sensory properties of milk protein ingredients. Springer, New York, NY.

Sodini, I., F. Remeuf, S. Haddad, and G. Corrieu. 2004. The relative effect of milk base, starter, and process on yogurt texture: A review. Crit. Rev. Food Sci. Nutr. 44:113-137.

Tahsiri, Z., M. Niakousari, S. Khoshnoudi-Nia, and S. M. H. Hosseini. 2017. Sensory evaluation of selected formulated milk barberry drinks using the fuzzy approach. Food Sci. Nutr. 5:739-749.

Vardhanabhuti, B., and E. A. Foegeding. 1999. Rheological properties and characterization of polymerized whey protein isolates. J. Agric. Food Chem. 47:3649-3655.

Vardhanabhuti, B., E. A. Foegeding, M. K. Mcguffy, C. R. Daubert, and H. E. Swaisgood. 2001. Gelation properties of dispersions containing polymerized and native whey protein isolate. Food Hydrocoll. 15:165-175.

Vianna, F. S., A. C. V. C. S. Canto, B. R. C. D. Costa-Lima, A. P A. A. Salim, M. P. Costa, C. F. Balthazar, B. R. Oliveira, R. P. Rachid, R. M. Franco, and C. A. Conte-Junior. 2017. Development of new probiotic yoghurt with a mixture of cow and sheep milk: Effects on physicochemical, textural and sensory analysis. Small Rumin. Res. 149:154-162.

Wang, H., C. Wang, M. Wang, and M. Guo. 2017. Chemical, physiochemical, and microstructural properties, and probiotic survivability of fermented goat milk using polymerized whey protein and starter culture kefir mild 01. J. Food Sci. 82:2650-2658.

Wang, W., Y. Bao, G. M. Hendricks, and M. Guo. 2012. Consistency, microstructure and probiotic survivability of goats' milk yoghurt using polymerized whey protein as a co-thickening agent. Int. Dairy J. 24:113-119.

Yadav, J. S., S. Yan, S. Pilli, L. Kumar, R. D. Tyagi, and R. Y. Surampalli. 2015. Cheese whey: A potential resource to transform into bioprotein, functional/nutritional proteins and bioactive peptides. Biotechnol. Adv. 33:756-774

Zhang, T., J. Mccarthy, G. Wang, Y. Liu, and M. Guo. 2015. Physiochemical properties, microstructure, and probiotic survivability of nonfat goats' milk yogurt using heat-treated whey protein concentrate as fat replacer. J. Food Sci. 80:M788-M794. 